\title{
DE PABLO A SAULO: TRADUCCIÓN, CRÍTICA Y DENUNCIA DE LOS LIBROS PLÚMBEOS POR EL P. IGNACIO DE LAS CASAS, S. J.
}

\author{
RAFAEL BENÍTEZ SÁNCHEZ-BlaNCO \\ Universidad de Valencia
}

El padre Ignacio de Las Casas es uno de los personajes principales de la fascinante historia de los libros plúmbeos de Granada. Interviene en ella interpretando varios papeles: comenzó en primer lugar como traductor y defensor de alguno de los libros; pasó de forma casi inmediata al de crítico intelectual del contenido de los plomos, y finalmente acabó como denunciante ante los más altos ámbitos del poder político y eclesiástico. En este artículo pretendo pasar revista a estos tres aspectos de su actuación y en particular a los argumentos que utiliza para denunciar la doctrina de los libros y los efectos que, en su opinión, puede tener sobre los moriscos. El P. Francisco de Borja de Medina aportó numerosas noticias de su vida y de su postura sobre la evangelización de los moriscos ${ }^{1}$. Su tarea como traductor al servicio de la Inquisición fue estudiada por Ana Labarta ${ }^{2}$. Pero es sobre todo en los estudios sobre los libros plúmbeos donde las referencias a su figura son constantes. Ya Godoy Alcántara señaló la polémica intervención de Las Casas en la traducción de los plomos y en la batalla posterior:

Trajeron [...], en malhora, a un jesuita morisco llamado el P. Casas, quien, resentido por cuestiones de amor propio, según se dijo, o instigado por deberes de conciencia, levantó la voz apellidando heterodoxa la doctrina de los libros; quitáronle al punto de Granada sus compañeros, temerosos de la impopularidad que iba a arrojar sobre la orden; pero desde los puntos adonde fue trasladado escribió a la Inquisición, al Nuncio, al cardenal Baronio y al Papa, yéndose por último a

1 De Medina, F. de Borja, S. J., "La compañía de Jesús y la minoría morisca (1545-1614)", Archivum Historicum Societatis Iesu, LVII (1988), 4-137.

${ }^{2}$ Labarta, A., "Notas sobre algunos traductores de árabe en la Inquisición Valenciana (1565-1609)", Revista del Instituto Egipcio de Estudios Islámicos en Madrid, XXI (1981-82), 101-133, en especial 108-11.

Al-Qanțara XXIII, 2 (2002) 403-436 
Roma, donde, como encarnizado enemigo, hizo a las láminas moriscas crudísima guerra $^{3}$.

Resume este párrafo lo fundamental de su actuación en el asunto de los plomos, cuyo detalle puede verse en el libro de Carlos Alonso ${ }^{4}$, en donde, por cierto, se juzga la lucha de Las Casas motivada por "deberes de conciencia", mientras que Zótico Royo, en las durísimas páginas que le dedica, le condena como "resentido por cuestiones de amor propio" 5 . Como trataré de demostrar, ambos factores están presentes en su actuación, si bien debemos concederle que el principal fuera el primero. No es el de los plomos del Sacromonte un tema en el que la historiografia haya brillado por la serenidad. En mi caso debo confesar que mis fuentes son los escritos del propio Ignacio de Las Casas, y que sus memoriales y cartas están profundamente influidos por un afán de justificar su actuación, sometida a crítica por el arzobispo de Granada, Pedro de Castro, y que muy posiblemente - es una cuestión en la que habría que profundizar - no era bien vista por la Compañía de Jesús. Como toda literatura con un alto componente de tipo personal, sus escritos, en los que abundan declaraciones de humildad y protestas de buscar el bien de la Iglesia y de la Monarquía, tratan de defender su trayectoria en el espinoso asunto del Sacromonte granadino. Constatar esta realidad no le invalida completamente como fuente de información. Por una parte, porque no estamos ante memorias autojustificativas plenas, ya que su intención política, que no es otra que lograr que Roma intervenga en la calificación de los libros plúmbeos, supera el afán defensivo. Éste, no obstante, se manifiesta con claridad en bastantes pasajes. Además, como ante cualquier otro texto, se trata de estar en guardia ante las intenciones particulares del autor.

${ }^{3}$ Godoy Alcántara, J., Historia crítica de los falsos cronicones, Madrid, 1868, 109. Dedica a los hallazgos del Sacromonte el cap. II y parte del VII, además de las páginas 4-7 en que trata del pergamino y reliquias encontradas en la torre Turpiana en 1588, antecedente de los plomos (recientemente, en 1999, se ha publicado una reedición facsímil en la colección Archivum de la Universidad de Granada, con un estudio preliminar de Ofelia Rey Castelao).

${ }^{4}$ Alonso, C., O.S.A., Los apócrifos del Sacromonte (Granada), Valladolid, 1979, cap. X y passim.

${ }_{5}$ Royo Campos, Z., Reliquias martiriales y escudo del Sacromonte, Granada, 1960, edición facsímil en la colección Archivum de la Universidad de Granada, 1995, con una introducción de Miguel L. López Muñoz. En especial el cap. XII donde recoge, además de múltiples improperios, importantes textos del archivo del Sacromonte. 
Son numerosos, en efecto, los memoriales y cartas que Ignacio de Las Casas escribió sobre los plomos, primero a favor y después, y de forma mucho más tenaz, en contra. No se ha localizado, que yo sepa, su declaración en forma de proceso ante la Inquisición realizada en Madrid en 1598 que, por la cercanía a su intervención, lo solemne del momento y las referencias que a ella hace, debe ser la exposición más completa de su parecer. Me voy a basar, por tanto, en el último y más extenso de sus memoriales de denuncia: Información de las láminas, libros y lo demás hallado en la ciudad de Granada y cerca de ella el año de 1588 dada a Nuestro Santíssimo P.e Paulo V por Ignacio de Las Casas, de la Compañía de Jesús, en este año de $1607^{6}$. Este texto, que Carlos Alonso reconoce no haber localizado, ha sido citado, de forma amplia en algunos casos, por Gaspar Morocho Gayo en su introducción al Discurso sobre el pergamino y láminas de Granada de Pedro de Valencia ${ }^{7}$, que se encuentra recogido en el mismo volumen. No obstante, creo que hay numerosos aspectos que merece la pena destacar a la espera de que pueda aparecer el proceso inquisitorial ${ }^{8}$. Como complemento utilizaré un memorándum realizado en Ávila en 1605, después de sus años de estancia en Valencia. Lo elaboró para el papa Clemente VIII, a petición del Nuncio Ginnasio,

\footnotetext{
${ }^{6}$ Está incluida en una relación de cartas y memoriales atacando la autenticidad de lo descubierto en Granada, recogidas por Adán Centurión, marqués de Estepa, que hace anotaciones críticas después de cada texto. Se trata, sin duda, de un texto preparado como segunda parte de su obra: Información para la historia del Sacromonte, llamado de Valparaíso y antiguamente Illipulitano junto a Granada, Primera parte, Granada, por Bartolomé de Lorençana, 1623. Es un libro difícil de encontrar por haber sido retirado por la Inquisición. He utilizado el ejemplar de la Biblioteca Apostólica Vaticana, Stamp. Barb. U. IX/55.

De la segunda parte existen varios copias manuscritas, como son las de la BNE, ms. 7187 y la Biblioteca Universitaria de Valencia, ms. 637/7 (no incluye el parecer de P. de Valencia ni las anotaciones del marqués de Estepa). He utilizado la de la British Library, Additional 57490. Lleva el título Reliquias de Granada, y perteneció a Sir Thomas Kendrick, que lo donó a la biblioteca. Los escritos de Las Casas contenidos en él son: Carta al cardenal Roberto Belarmino (ff. 81v.-84), carta al cardenal César Baronio (ff. 84-85), y la Información... a Paulo $V$ (ff. 85-139). Se completa con las notas del marqués de Estepa (ff. $139-157 \mathrm{v}$.)

7 Obras completas de Pedro de Valencia, vol. IV-2 Escritos políticos, León, Universidad de León, 2000, 143-426.

8 Por mi parte hice una breve presentación de las ideas de Las Casas, tomadas del memorial al Inquisidor General — que se cita a continuación-, en una comunicación a la VI Reunión Científica de la Fundación Española de Historia Moderna, celebrada en Alcalá de Henares en junio de 2000, titulada: "Mesianismo y milenarismo morisco: los plomos del Sacromonte en la interpretación del jesuita Ignacio de las Casas", que se encuentra en prensa.
} 
pero, debido a la muerte del Pontífice (marzo de 1605) y a la marcha del Nuncio a Roma, optó por enviarlo, resumido, al Consejo de Inquisición, y no aparece citado en el libro de Carlos Alonso ${ }^{9}$.

Educado en el colegio del Albaicín primero y después en Montilla y Córdoba, marchó a Roma en la coyuntura de la guerra de Granada y allí, en 1572, profesó en la Compañía de Jesús. Después de unos años completando su formación en Italia, fue destinado a la provincia de Castilla. En 1579 se encontraba, ya sacerdote y habiendo adoptado el apellido paterno de Las Casas, en Segovia. En 1581 fue llamado a Roma por el padre general Aquaviva, debido a la apostasía y huida a Berbería de un hermano suyo. Gracias a su conocimiento del idioma, fue designado penitenciario menor de San Pedro de Roma para la lengua árabe y en 1583-84 participó, en compañía del P. Leonardo Sant-Angelo, en la embajada enviada por Gregorio XIII a los patriarcas orientales. Esto le permitió entrar en contacto con un abigarrado mundo de creencias: cristianos maronitas, melquitas, judíos sefardíes, renegados, musulmanes... Es una experiencia que recuerda en varios de sus escritos y que va a influir decisivamente en su interpretación de los libros plúmbeos.

En 1587 regresó a España, donde completó sus estudios en Gandía, Valencia y Alcalá. Al concluir éstos en 1593, estuvo destinado en varios colegios de la provincia de Castilla ${ }^{10}$. En la carta al cardenal Belarmino da una breve semblanza autobiográfica ${ }^{11}$ :

No será necesario darme a conocer [...], pienso se acordará luego de mí, así por haverme conocido aý en el colegio romano tanto tiempo y haver sido discípulo de V. S. I. y singular por la lengua arábiga como por saber V. S. I. que fui a Jerusalem con el P. Leonardo S. ${ }^{\mathrm{n}}$ Angelo en compañía del obispo de Sidonia, criado

9 British Library, Additional 10238, ff. 161-187v. Se trata de un libro autógrafo que contiene diversas cartas y memoriales de Las Casas, junto con otros materiales y documentos sobre los moriscos. Fue utilizado ampliamente por el P. De Medina en su trabajo citado. Sobre la estancia en Avvila, véase Alonso, C., Los apócrifos, 178. Sobre la elaboración del memorial, vid. la carta al Inquisidor General, Juan Bautista de Acebedo, ff. 161-162.

${ }^{10}$ Estas noticias sobre su vida están tomadas del trabajo del P. De Medina, "La compañía de Jesús y la minoría morisca...", 6-8.

11 BL, Add. 57490, ff. 81v- 82. 
que fue del Illmo. Sta. Severina. El haver savido esta lengua arábiga que digo medianamente me ha siempre dado ocasión de desear con veras hacer algún fruto según el instituto de la Compañía en las ánimas de los de esta lengua, y en particular de los que de ella ay en estos Reynos de España, que son más de la tercera parte de ellos. Y así luego que bolbí a estas partes de la misión de Oriente, y de haver estado en esa Penitenciería de $\mathrm{S} .^{\mathrm{n}}$ Pedro procuré acabar mis estudios de Theología sólo para emplearme todo en esto conociendo quan destruidas están estas almas del socorro que se les debe dar estando ellas en el riñón de la Iglesia y tenidas por hijos de ella. Es tan lastimoso el estado de esta gente y por ella el de toda España que tengo por cierto que entendido de V. S. I. tomará con veras el acudir a su remedio porque conocerá que es maior y más lastimoso que todas las heregías ultramontanas y más digno de ser remediado por vía de los maestros que el acudir tantos de nuestra compañía a las dos Indias.

\section{Y en 1597 volvió a Granada:}

Con ocasión de saber lo que he dicho de la lengua arábiga permitió el Señor que yendo a Granada, que es donde yo nací, viese por orden del Arzobispo de aquella ciudad algunos libros que hallaron cerca de ella, escritos en plomo ${ }^{12}$.

En efecto, cayó el P. Las Casas en el momento en que se estaban descubriendo en el monte de Valparaiso - tal es la denominación antigua que da Ignacio de Las Casas al hoy conocido como Sacromonte- huesos humanos acompañados de láminas de plomo que explicaban que eran reliquias de antiguos mártires, y que anunciaban la aparición de libros escritos también en láminas de plomo. Los descubrimientos habían tenido como prólogo el hallazgo en 1588 de una caja de plomo conteniendo un pergamino escrito en árabe, castellano y latín, junto con un lienzo y el hueso de un brazo humano. Apareció entre los escombros del campanario de la catedral granadina, antiguo alminar de la mezquita, que se estaba derribando para la ampliación del templo catedralicio.

Sabe V. Al., que el año de mil y quinientos y ochenta y ocho derribando en Granada la torre del campanario viejo dizen que se halló entre las piedras y materiales que avían caydo una caxa de plomo. En ella estava un pergamino escrito la mayor parte en letra y lengua arábiga y parte en castellano, cada letra en una casilla como axedrez, una negra y otra colorada, con ciertas letras griegas como cotas; ay algo en latín. Con este pergamino estava también un pedaço de lienço y un huesso. Sobre este pergamino y lo en él contenido, con lo que estava en la caxa, ubo varios y grandes discursos en tiempo del arçobispo don Joan Méndez de Salvatierra, el qual lo recogió y escondió sin querer que se hablasse en ello ${ }^{13}$.

12 Id., f. 83.

13 BL, Add. 10238, f. 180. 
En la interpretación del texto árabe, que estaba escrito en cuadrados rojos y negros, como un rompecabezas sobre un tablero de ajedrez, participaron los médicos traductores moriscos Alonso del Castillo y Miguel de Luna. Como explica Las Casas, que describe el pergamino de la torre Turpiana y expone su contenido "sacado del cap. 13 del Discurso que imprimió el Dr. Madera ${ }^{14}$ de este monte de Granada":

Huvo por este tiempo varias interpretaciones de lo que estava en arábigo del pergamino y varias dudas de hombres doctos sobre él, las quales movieron al Prelado, que era entonces D. Juan Méndez de Salvatierra, a recoger esta caxa con lo que en ella havía sin hacer otra novedad alguna, ni la huvo en todo hasta el año $1595^{15}$.

En efecto, la autenticidad del pergamino de la torre Turpiana, que es como se denominaba en él al campanario, provocó una polémica en que participaron, entre otros, Luis del Mármol y Arias Montano. El primero presentó un "parecer" en el que se señala claramente la doble conexión del pergamino con Alonso del Castillo ${ }^{16}$. Por una parte, porque éste había manifestado tener noticias, desde varios años antes del levantamiento de 1568 , de que al derribar la torre Turpiana se hallaría en ella un gran pronóstico. Mármol, además, vincula el sentido del pergamino con dos jofores o "pronósticos de moros" que fueron traducidos por Alonso del Castillo y que él publicó en su Rebelión ${ }^{17}$. Denuncia, también, como sospechosa la diligencia con que Luna acudió a traducir el pergamino. La participación de Castillo y Luna en la puesta en escena de la farsa recibe, así, un cierto respaldo documental por parte de alguien muy bien informado sobre el mundo granadino y norteafricano, como era Mármol, aunque sin llegar a confirmarse la autoría plena que Godoy les atribuye. Arias Montano llegó a ver el original del pergamino que el arzobispo de Granada, Pedro de Castro, le hizo llegar a Sevilla. Su informe, basado en el principio "de no ad-

\footnotetext{
14 Se refiere a López Madera, G., Discurso de la certidumbre de las reliquias descubiertas en Granada desde el año 1588 hasta el de 1598, Granada, 1601. El Ldo. Gregorio López Madera es uno de los primeros defensores de los hallazgos.

${ }^{15}$ BL, Add. 57490, f. 91v.

16 Fue descubierto y estudiado por Cabanelas Rodríguez, D., O.F.M., El morisco granadino Alonso del Castillo, Granada, 1965, en cuyos dos últimos capítulos se ocupa del pergamino de la torre Turpiana y del enigma de los libros plúmbeos.

17 Mármol Carvajal, L. del., Historia del rebelión y castigo de los moriscos del Reino de Granada, Málaga, 1600, libro III, cap. 3. Véase la edición de la Biblioteca de Autores Españoles, 21, Historiadores de sucesos particulares, vol. I, Madrid, 1946, 169-174.
} 
mitir las cosas inciertas por ciertas", desautorizaba completamente el pergamino, del que afirmaba que "es viejo, empero no antiguo" 18.

En esta situación se encontraba el asunto cuando, en 1595, se produjeron nuevos descubrimientos. El P. Las Casas, en su informe a la Suprema, lo resume:

\begin{abstract}
El año de mil y quinientos y noventa y cinco en un monte fuera de la ciudad se hallaron ciertas láminas de plomo escritas con letras mal formadas latinas y con ellas quantidad de huessos y cenizas y otros libros de plomo escritos en letra y lengua arábiga, y hasta el año de mil y quinientos y noventa y ocho se fueron hallando quantidad de estos libros arábigos ${ }^{19}$.
\end{abstract}

En efecto, según el relato que da Carlos Alonso, resumiendo las numerosas relaciones de los descubrimientos, el 21 de febrero, unos buscadores de tesoros, vaciando los materiales que rellenaban una cueva en el cerro de Valparaíso encontraron una laminilla de plomo con un breve texto en latín de difícil lectura ${ }^{20}$. Fue descifrada el 15 de marzo por el jesuita P. Isidoro García: era una inscripción funeraria que decía: "Corpus ustum Divi Mesitonis Martiris, pasus est sub Neronis potentatu" ${ }^{21}$. Continuando las excavaciones, ahora por cuenta del arzobispo, el 21 de marzo se descubrió otra lámina, también latina. Era del mismo tipo y anunciaba que en aquel Sacro Monte estaban enterradas las cenizas de San Hiscio, discípulo de Santiago, y de sus discípulos Turilo, Panucio, Maronio y Centulio, quemados vivos en el año segundo del imperio de Nerón. Al día siguiente aparecieron cenizas blancas que se completaron, poco después, con el descubrimiento de huesos humanos calcinados. El 10 de abril se encontró la tercera lámina. Hacía referencia a los restos de los mártires San Tesifón, también discípulo de Santiago, y de sus discípulos Maximino y Lupario.

\footnotetext{
18 Morocho, G., Estudio introductorio..., 226-228 y apéndices I. 2, I. 3, 361-367. Su informe está fechado el 4 de mayo de 1593.

19 BL, Add, 10238, f. 180.

${ }^{20}$ Las Casas lo expone así: "Se dice que cabando unos hombres en una cueva que está en él, por hallar un tesoro, hallaron una lámina de plomo en el año 1595, por el mes de marzo". Y a continuación explica cómo eran las láminas: "Unas planchas de plomo de más de una quarta de largo, la letra que tienen es al parecer hecha a golpes con algún hierro algo boto, y el que las escribió, que al parecer fue uno en todas, no savía mucho de escribir así" (BL, Add. 57490, f. 92).

${ }^{21}$ Ibid. Según la traducción publicada por Miguel José Hagerty: "Cuerpo quemado de San Mesitón mártir. Padeció bajo el poder del emperador Nerón”. Hagerty, M. J., Los libros plúmbeos del Sacromonte, Madrid, Biblioteca de visionarios, heterodoxos y marginados, 1980, 307. En esta obra puede verse la traducción efectuada por el marqués de Estepa.
} 
Pero lo novedoso, con relación a las dos anteriores, era que indicaba que Tesifón, antes de convertirse, se llamaba Aben Attar y que había escrito en tablas de plomo un libro titulado Fundamentum Eclesiae que se encontraba enterrado con las cenizas de los mártires. Tras varios hallazgos de cenizas y huesos humanos, el 22 de abril aparecieron cinco laminillas de plomo, redondas, escritas en árabe por ambas caras, cubiertas por otra escrita en latín que contenía el título: Liber fundamentum Ecclesiae, Salomonis caracteribus scriptus. Tres días después, el 25 de abril, apareció otro libro semejante formado por tres láminas redondas y una cubierta de plomo más gruesa: era el Liber de essentia Dei, escrito por San Tesifón en su lengua arábiga materna y en caracteres de Salomón. En la cubierta se hacía referencia a que había escrito además el llamado Fundamentum Ecclesiae ${ }^{22}$. El 30 de abril se encontraba una cuarta lámina latina; en ella se hacía mención al martirio de San Cecilio y de sus discípulos Septentrio y Patricio. Y, cerrando el círculo, declaraba que San Cecilio había escrito un comentario a las profecías de San Juan, que, junto con otras reliquias, estaban puestas en la torre Turpiana.

Entre septiembre de 1596 y abril de 1597 aparecieron otros seis libros. Ignacio de Las Casas da la relación de estos primeros hallazgos anteriores a su llegada a Granada ${ }^{23}$ :

Libros que se hallaron

1. Fundamentum Ecclesiae: éste se halló a 22 de abril de 1595.

2. De Esentia Dei: éste se halló a 25 del dicho mes y año.

3 y 4 . Tercero y quarto son cathecismos ${ }^{24}$.

5. Misa de los Apóstoles ${ }^{25}$.

${ }^{22}$ Según la transcripción de Las Casas: "Liber de esentia Dei, quem Divus Thesiphon Apostoli Jacobi Discipulus in sua naturali lingua Arabica Salomonis caracteribus scripsit et alium fundamentum Ecclesie appelatum, qui in hujus sacri Montis cavernis jacet, Deus a Nerone imperatore hos duos liberet libros: imposuit finem hic: in suis operibus scribenes miracula et vite inte...itamem sui magistri ... vi in hujus sacri Montis ca... est" (deja en blanco ciertos pasajes que se supone no se leían). BL, Add. 57490, f. 93v-94.

${ }^{23} \mathrm{Ibid}$., f. 94.

24 El primero, hallado el 16 de octubre de 1595, corresponde al Liber excellentis beati Apostoli Iacobi...; véase el título completo en: Alonso, C., Los apócrifos, 107, n. ${ }^{\circ} 3$, que sigue a Centurión, A., Información para la historia del sacromonte. En él debe incluirse el Llanto de San Pedro (Plantus Petri...) que otros autores, como Godoy Alcántara (Historia crítica, 54-55) dan como un tratado separado. El segundo debe de tratarse del llamado Catecismo menor (Alonso, C., Los apócrifos, 109, n. ${ }^{\circ}$ 6). Se encontró el 24 de abril de 1596.

${ }^{25}$ Liber modi (celebrandi) Missam a Iacobo Apostolo...; ibid., 106, n. ${ }^{\circ}$ 2, aparecido el 1 de octubre de 1595 . 
6. Oración de Santiago ${ }^{26}$.

7. Primera parte de Providencia ${ }^{27}$.

8. Excelencias de la Fee ${ }^{28}$.

Éstos no sé quándo ni cómo se hallaron ni por qué orden.

Como él manifiesta, permaneció en Granada desde junio de 1597 hasta abril de $1598{ }^{29}$. En este período siguieron apareciendo más libros.

Estando yo en Granada el año de 1597 desde el mes de junio hasta el de abril del año siguiente se hallaron:

9. Segunda parte de Providencia ${ }^{30}$, con el qual estaban juntos tres tratados: Primero De Angelis ${ }^{31}$; Segundo: De annulo Salomonis ${ }^{32}$; Tercero: De Beata Patria et inferno ${ }^{33}$.

10. De la historia de la verdad del Evangelio glorioso ${ }^{34}$.

11. Ensalzamiento de la Virgen a los altos misterios de Dios ${ }^{35}$.

12. Es un libro ilegible que no ay quien entienda qué letra es ni lo que dice $^{36}$.

Estos tres libros últimos ${ }^{37}$ estavan en una piedra de poco más de una quarta en largo y poco más de ocho dedos en ancho, si bien me acuerdo, porque ha ya años 1595.

${ }^{26}$ Oratio et defensivum Iacobi...; ibid., 106, n. ${ }^{\circ}$ 1, encontrado el 20 de septiembre de

${ }_{27}$ Pars prima assequibilium divinae potentiae et clementiae et directionis erga servos...; ibid., 108, n. ${ }^{\circ}$ 5, encontrado el 2 de enero de 1596.

${ }_{28}$ No hay ninguno con ese título; el único que falta de la relación de los encontrados hasta entonces es: Liber bonorum actorum Domini Nostri Iesu Christi et Virginis Mariae, matris eius, et vitae illius et miraculorum illius..., que se descubrió el 23 de noviembre de 1595 y cuyo contenido es básicamente la vida de la Virgen y de Cristo en el estilo de los evangelios apócrifos. Ibid., 108, n. ${ }^{\circ}$. Me inclino a pensar que le ha fallado la memoria y que se refiere al Libro de las sentencias de le ley (Liber sententiarum erga legem et directionem...; ibid, 110, n. ${ }^{\circ} 8$ ), aparecido el 4 de septiembre de 1597, cuando Las Casas ya estaba en Granada, y que no menciona en la siguiente relación.

29 No sé de dónde proviene la equivocación de Carlos Alonso, que afirma que Las Casas trabajó en la traducción de parte de los libros "por espacio de un año o poco más, aproximadamente desde la primavera de 1596 hasta el mes de junio de 1597" (Los apócrifos, 148-149).

${ }^{30}$ Pars altera assequibilium divinae potentiae et clementiae...; ibid., 109, n. ${ }^{\circ} 7, \mathrm{I}$. Apareció el 27 de agosto de 1597.

31 "De la naturaleza del ángel y de su poder..."; ibid., 110, n. ${ }^{\circ} 7$, IV.

32 Liber historiae signi Salomonis; ibid., 109, n. ${ }^{\circ} 7$, II.

33 Debe tratarse, por exclusión, de "Relación de la casa de la paz y de la venganza y de los tormentos..."; ibid., 110, n. $^{\circ} 7$, III.

${ }^{34}$ Liber historiae Certificationis Evangelii gloriosi...; ibid., 111, n. ${ }^{\circ} 9$, II.

${ }^{35}$ Liber colloquii Santae Mariae Virginis. Liber notitiarum mysteriorum quae vidit Sancta Maria Virgo per gratiam Dei in nocte colloquii sui spiritualis cum eo... ; ibid., $111,{ }^{\circ}{ }^{9}$, III.

${ }^{36}$ Liber Certificationis Evangelii (Hakikat Lenguil); Ibid., 111, n. ${ }^{\circ}$, I.

37 Aparecieron el 31 de diciembre de 1597. 
que la vi, en esta estavan tres concavidades hechas con compás redondas bien entalladas, y en ellas estavan los tres libros dichos. Tenía por cubierta otra piedra tambien ajustada con la dicha que de repente se juzgava ser una. El ilegible estava en medio.

Son estos libros de delicadas hojas de plomo redondas al tamaño de Hostias no muy grandes, aunque ay algunos mayores que otros. Sólo uno es obalado pequeño que contiene la oración que dicen de Santiago. La letra es de dos formas o manos bien diferentes galanamente exarada ${ }^{38}$ en el plomo al modo que escriben los arábigos en regla y planchas de las quales he visto muchas y se vee que está cortada con buril en la forma y modo siguiente y están por ambas partes escritas ${ }^{39}$.

Ignacio Las Casas en su informe a la Suprema afirma que: "Hago mención de doze [libros] en la carta que digo escreví a esse Supremo Consejo, que está en el proceso dicho. Dízese que an llegado a veynte o más. No lo sé cierto" ${ }^{40}$. Si bien después de su marcha de Granada aparecieron cuatro libros más ${ }^{41}$, lo que hacía, en efecto, un total de veinte libros, la diferencia de cómputo se debe a que bajo el número 9, Las Casas ha incluido cuatro libros, lo que sumado al que falta en su lista - muy posiblemente el Libro de los actos de Jesús y Maríaeleva la relación a veinte.

En el verano de 1597 en que Las Casas volvió a su ciudad natal de Granada, el arzobispo Pedro de Castro había conseguido grandes éxitos políticos, ya que la Corte había dado el visto bueno al proceso instruido en Granada y le instaban a reunirse con los obispos sufragáneos para efectuar la calificación de las reliquias y para sugerir lo que debía escribirse a Roma sobre los libros plúmbeos. Por otra parte, tanto el Nuncio como el Papa le autorizaban a calificar las reliquias según lo establecido en Trento ${ }^{42}$. El jesuita comenzó su colaboración como traductor trabajando sobre el libro Fundamentum Ecclesiae.

${ }^{38}$ Del latín 'exaro' = trazar [sobre la cera], escribir.

39 BL, Add. 57490, f. 94v-95.

40 BL, Add, 10238, f. 108.

${ }^{41}$ Los dos primeros aparecieron el 11 de mayo de 1599, y son: Liber donorum, remunerationum Certificationem Evangelii credentibus..., y el Liber mysteriorum magnorum quae vidit Iacobus Apostolus in Monte Sancto...; Alonso, C., Los apócrifos, 113, n. ${ }^{\circ} 10$, I y II. Los dos últimos corresponden a las dos partes del Libri actuum Iacobi Apostoli que llegaron a manos del Arzobispo en diciembre de 1607, pero que se habían descubierto unos ocho años antes; ibid., 113-114, $\mathrm{n}^{\circ} 11$.

42 Para esto, como para todas las actuaciones, es fundamental la obra citada de Carlos Alonso, Los apócrifos. Lo mencionado, en las páginas 140-143. 
Éste fue el primero que vino a mis manos. Tiene el título siguiente: Libro de los Fundamentos de la Ley, o Libro de los Artículos de la Ley de Thesifon discípulo de Jacobo apóstol. En solas cinco hojas comprehende casi todos los Artículos de la $\mathrm{Fe}$ con alto y grave estilo y lenguaje y me persuadí al principio que era el símbolo o concilio que hicieron los Apóstoles antes del martirio del glorioso Santiago apóstol, antes de dividirse a la predicación, y no estoy de contrario parecer aunque le ayan añadido hereges algo para sus intentos como suelen ${ }^{43}$.

La admiración que le causó el libro le hizo escribir una carta laudatoria al Arzobispo. Al menos eso es lo que afirma el marqués de Estepa en la primera parte de su obra, donde reproduce la carta ${ }^{44}$, mientras que para Gaspar Morocho ésta "problablemente sea falsa" 45 . Sin poder tajantemente negar la probabilidad — nada extraño en el marco de invenciones que analizamos - hay que señalar que lo fundamental de su contenido se ajusta a lo afirmado por Las Casas años después, como se ve en el párrafo siguiente ${ }^{46}$ :

Lo que hallo es ser todo la suma de nuestra fe tan alta y theológicamente puesta que, a mi juicio, si se quisiese poner mexor o con más significativos y propios términos ni más sucintas palabras, no se podría [...] Hallo últimamente que es un concilio auténtico que el santo Thesifón afirma averse hecho por los Apóstoles congregados por el immenso Señor que los llamó al apostolado. Y certifica que su sagrado maestro y patrón nuestro [Santiago] le mandó lo escriviese...

O en este otro, unas páginas más adelante ${ }^{47}$ :

$\mathrm{Y}$ así digo que este santo libro es fino y elegante arábigo y no ya conforme a los ritmos o metros de los moros, sino en estilo christiano llano y sin composiciones, que son más de ornamento que de provecho, como lo usan las escrituras sagradas pero tan alto y grave que se descubre bien ser composición sagrada y cosa del Espíritu Santo.

No queda claro si llegó a traducir completamente el libro de Essentia Dei. En el memorándum para la Suprema lo cita entre los que tradujo, pero ni explica su contenido ni vuelve a mencionarlo ${ }^{48}$ :

43 BL, Add. 57490, ff. 105v.-106.

44 Centurión, A., Información para la historia del Sacromonte, 119-125. He visto también una copia en la BL, 1322.1.9.

45 Morocho Gayo, G., Estudio introductorio, 273, nota 420

46 Centurión, A., Información para la historia del Sacromonte, 119v-120.

47 Ibid., 122.

48 BL, Add. 10238, ff. 181v-182. Adán Centurión dice que ayudó a traducir tanto el Fundamentum Ecclesiae como el Essentia Dei, y que después escribió la carta laudatoria al Arzobispo. Pero en ésta sólo hace referencia al primero. 
se dixese que un sacerdote de la Compañía los havía interpretado y autorizado como por poder desde lexos escribir al Arzobispo mi parecer para que constase ${ }^{53}$.

La explicación que los defensores de las reliquias dan a su huida se basa en su incompetencia como traductor y su afán de protagonismo, que le llevaba a despreciar el trabajo de los otros intérpretes cuando sus propias anotaciones reflejaban sus problemas para interpretar los textos. Y aprovechan para echarle en cara su origen morisco ${ }^{54}$.

La capacidad del P. Las Casas como traductor y su relación con los otros, y en especial con Miguel de Luna y Alonso del Castillo, plantea uno de los principales interrogantes de su intervención en el asunto de los libros plúmbeos. A falta de un análisis detallado de su trabajo, que no está en mi mano efectuar, quiero señalar algunas de sus reflexiones sobre la dificultad de los textos y el trabajo, propio y ajeno, de interpretación. La citada carta al Arzobispo es, en gran parte, una memoria sobre la traducción. Comienza exponiendo los problemas del texto del Fundamentum Ecclesiae: 1) "Dificultad de la letra y lengua"; 2) "Variedad de sentidos que se le pueden dar no estando apuntado"; 3) "El estilo, nombres y verbos que tiene, que a prima faz al que no supiere mucho de la lengua arábiga parecerá o que ya no los usa tanto la lengua, o que los escrive de otra forma o manera, o los toma en algo diversa significación". Con ello no hace más que constatar lo que había dicho poco antes Arias Montano con relación a la copia del pergamino que le habían enviado ${ }^{55}$ :

No lo leerán quatro que entiendan la lengua sin variar en muy muchos lugares en grande manera, porque no solamente carece de xuclas o haracas, que son las vocales (que esto no hace mucho negocio a quien esté diestro en leer), sino lo que más importa: está falto de los puntos sustanciales de las letras consonantes y por esto juzgo yo que hará adivinar a los ingenios...

La opinión de Las Casas sobre el pergamino coincide con la del humanista ${ }^{56}$ :

${ }^{53}$ BL, Add. 57490, ff. 129v-130.

54 Royo, Z., Reliquias martiriales, cap. XII, 102-105. También el marqués de Estepa insiste en su carácter morisco y en su limitado conocimiento del árabe: "Sabía algo de la lengua árabe (aunque no mucho de la antigua)" (Información para la historia del Sacromonte, 118v.).

${ }^{55}$ Carta de Arias Montano al arzobispo Castro, 10 de noviembre de 1596. Morocho, G., Estudio introductorio, apéndice I.14, 383.

56 BL, Add. 57490, f. 99. 
lomón, la Historia de la verdad del Evangelio y el Ensalçamiento de la Virgen a los altos secretos de Dios. Analiza también el pergamino de la torre Turpiana, pero no queda claro si lo estudió directamente o, más bien, a través de las obras de otros autores, defensores y críticos de su validez. Cita, por último, algún pasaje del que llama libro aovado, es decir de la Oración de Santiago, pero es posible que se limite a seguir a Arias Montano.

Si aceptamos como auténtica la carta ensalzando el libro Fundamentum Ecclesiae, es innegable que pasó de la aceptación al rechazo. En este proceso fue decisivo el estudio del contenido de algunos de los libros que aparecieron durante su estancia en Granada, el considerar lo relacionados que estaban los libros con las reliquias, las láminas y el pergamino, y muy posiblemente el conocimiento, todavía en Granada, de las críticas de Arias Montano y otros al pergamino y a las láminas. Las Casas se percató no sólo del contenido heterodoxo de los libros, sino de que, a través de las láminas, éstos enlazaban íntimamente con las reliquias y con el pergamino hallado en la torre Turpiana. Formaban un todo indisoluble. Intentó convencer el arzobispo Castro de que no llevase a cabo la calificación de la reliquias ${ }^{51}$ :

\footnotetext{
Considerando quán travadas están todas estas cosas entre sí, como se ve por las láminas y cubiertas de los libros, y que no se pueden dividir ni apartar, pues el maior testimonio de que aquellos huesos son de tal o tal santo consta de estas láminas y no de otra cosa, y ellas mismas dicen que aquéllos escribieron los libros, y por ser tan claro esto no lo dilato más, y el mismo Dr. Madera que defiende estas cosas confiesa que no se pueden apartar, antes que executase el Prelado la calificación le hize notable instancia que adbirtiese los errores que havía en los libros y la trabazón que tenían con lo demás y los grandes daños que resultarían a estos Reynos y a la Iglesia.
}

Lo llegó a intentar en una última entrevista personal que tuvieron en La Zubia el 14 de mayo de $1598{ }^{52}$, pero no lo consiguió.

Y viendo que no me dava las orejas que yo deseaba en negocio tan árduo y grave, y que quería proseguir a la calificación diciéndome que eran diferentes los libros de los huesos y cenizas, me salí de Granada sin su beneplácito así por que no

51 Id., f. 129.

${ }^{52}$ Lo trata Zótico Royo (Reliquias martiriales, cap. XII, 106-107) usando documentación del Sacromonte. 
En cuanto a su capacidad como intérprete y a la validez de su traducción, comparándola con las otras, ofrece Las Casas opiniones contradictorias. En la misma carta a Castro, que estoy comentando, el amor propio se mezcla con la obligada humildad, pero sale triunfante ${ }^{59}$ :

Lo que alcanzo de la lengua, que aunque no es para comparar con los demás intérpretes de V. S. (a todos los quales doi de muy buena gana la bentaxa y esto sin doblez porque lo siento así), pienso con todo eso que no es tan poco que no tenga alguna aptitud para juzgar por aver leído varios libros así en estilo de moros (cuia agora se tiene esta lengua propia por aver cundido tanto la diabólica seta del perverso Mahoma) [...] como también por aver leído muchos en este estilo de christianos.

Alega como mérito particular haber ayudado al P. Francisco de Torres o Turriano en la traducción de los cánones del concilio de Nicea. Por si fuera poco, resalta la rapidez con que logró entender la mayor parte del Fundamentum Ecclesiae "como vio V. S. I. pues dixo que en muchos meses no avían hecho los intérpretes lo que yo en pocos días" ${ }^{60}$. Uno de los problemas graves, en su opinión, era el desconocimiento que los otros traductores tenían de la Teología, lo que dificultaba su interpretación de los conceptos contenidos en los textos. El otro es que no actuaban con libertad, sino bajo las indicaciones del Arzobispo o de su entorno ${ }^{61}$ :

Añadí lo segundo, que supe por cosa cierta que quando interpretavan, que era siempre en presencia del Arzobispo o de otros por él, les decían quando topaban dificultades: “¡No puede decir así! ¿No dirá así?”. Con lo qual les impedían decir la verdad, más siendo ellos descendientes de los árabes y temerosos de no ser tenidos por hombres que decían contra la Fee, como dijeron ellos propios.

En una carta que escribe al Nuncio Ginnasio, y que éste remite a Pietro Aldobradino el 1 de julio de 1600 , es bastante más ácido ${ }^{62}$ :

Últimamente se advierta que las ynterpretaciones hechas por los yntérpretes que hasta aquí ha avido, aunque ellos saben bien la lengua arábiga bulgar y algo

59 Centurión, A., Información para la historia del Sacromonte, $120 \mathrm{v}$.

${ }^{60}$ Ibid., 119v.

61 En sus varios memoriales insistió en que "aunque los otros intérpretes que ha avido saven más de la lengua arábiga que no yo, no saven nada de las letras sagradas ni de otras facultades necesarias para la interpretación"; BL, Add. 57490, f. 136.

${ }^{62}$ ASV. Segret. di Stato. Spagna 53, f. 156 y ss. 
Muchas de las dicciones del arábigo que están en escaques están medio borradas y de tal suerte escritas que aun copiarlas ad verbum no han acertado los intérpretes, como se le hizo demostración clara al Arçobispo y él la reconoció. Ítem, leydas y juntadas en varios modos hacen varios y diversos sentidos.

En la carta a Castro, el jesuita expone su forma de trabajar. En primer lugar, no quiere que le muestren nada de lo realizado por los otros traductores para no verse influido. Después,

haré tres cosas: Lo primero porné el libro en la letra que el Santo lo exaró con tanto trabajo y cuidado, y luego en letra común arábiga como yo lo leo. Lo segundo, pondré en nuestro estilo y modo su exposición [...] y esto así en latín como en romance. Últimamente, procurando guardar la fidelidad del libro santo, pondré con los más significativos y verdaderos términos y correspondientes al arábigo, todo él ${ }^{57}$.

Es decir, copiará primero las láminas y efectuará a continuación una transcripción árabe. Basandose en estos primeros pasos, el arzobispo Castro llegó a negar su capacidad como traductor:

Este padre ningún libro ha leído por los originales ni interpretado por ellos, ni puede ni sabrá, porque no los puede leer. [...] Lo que hacía es que sacaba en papeles aparte traslados, no leyendo los originales, que no los sabe leer, sino sacando de su mano, como quien pinta, y por estos sus traslados leheía lo que agora dice que entiende; y esto así pintado, que tenemos acá, tiene mil mentiras y son claro testimonio de que no lo lehía ni entendía ${ }^{58}$.

Pero, como Las Casas había explicado al Arzobispo, no era más que el comienzo del proceso. En segundo lugar, realizará una versión libre latina y castellana del texto. Finalmente, revisará el texto buscando la traducción más precisa de los términos árabes. Es consciente de la dificultad de lograrlo dada la variedad de significados y propone como solución dar las varias lecturas posibles:

Y porque como dixe al principio tienen sus proposiciones varios sentidos en muchas partes, y todos cathólicos, los pondré correspondientes con las letras del $\mathrm{ABC}$ no mirando tanto a elegancia ni de la castellana ni latina cuanto al sentido del santo y propiedad de la lengua arábiga que es admirable en esta composición.

57 Centurión, A., Información para la historia del Sacromonte, 124.

58 Alonso, C., Los apócrifos, 153. Carta de Castro a D. Juan de Zúñiga, 13 de septiembre de 1598. 
En cuanto a su capacidad como intérprete y a la validez de su traducción, comparándola con las otras, ofrece Las Casas opiniones contradictorias. En la misma carta a Castro, que estoy comentando, el amor propio se mezcla con la obligada humildad, pero sale triunfante ${ }^{59}$ :

Lo que alcanzo de la lengua, que aunque no es para comparar con los demás intérpretes de V. S. (a todos los quales doi de muy buena gana la bentaxa y esto sin doblez porque lo siento así), pienso con todo eso que no es tan poco que no tenga alguna aptitud para juzgar por aver leído varios libros así en estilo de moros (cuia agora se tiene esta lengua propia por aver cundido tanto la diabólica seta del perverso Mahoma) [...] como también por aver leído muchos en este estilo de christianos.

Alega como mérito particular haber ayudado al P. Francisco de Torres o Turriano en la traducción de los cánones del concilio de Nicea. Por si fuera poco, resalta la rapidez con que logró entender la mayor parte del Fundamentum Ecclesiae "como vio V. S. I. pues dixo que en muchos meses no avían hecho los intérpretes lo que yo en pocos días" ${ }^{60}$. Uno de los problemas graves, en su opinión, era el desconocimiento que los otros traductores tenían de la Teología, lo que dificultaba su interpretación de los conceptos contenidos en los textos. El otro es que no actuaban con libertad, sino bajo las indicaciones del Arzobispo o de su entorno ${ }^{61}$ :

Añadí lo segundo, que supe por cosa cierta que quando interpretavan, que era siempre en presencia del Arzobispo o de otros por él, les decían quando topaban dificultades: “¡No puede decir así! ¿No dirá así?”. Con lo qual les impedían decir la verdad, más siendo ellos descendientes de los árabes y temerosos de no ser tenidos por hombres que decían contra la Fee, como dijeron ellos propios.

En una carta que escribe al Nuncio Ginnasio, y que éste remite a Pietro Aldobradino el 1 de julio de 1600, es bastante más ácido ${ }^{62}$ :

Últimamente se advierta que las ynterpretaciones hechas por los yntérpretes que hasta aquí ha avido, aunque ellos saben bien la lengua arábiga bulgar y algo

59 Centurión, A., Información para la historia del Sacromonte, 120v.

60 Ibid., 119v.

${ }^{61}$ En sus varios memoriales insistió en que "aunque los otros intérpretes que ha avido saven más de la lengua arábiga que no yo, no saven nada de las letras sagradas ni de otras facultades necesarias para la interpretación"; BL, Add. 57490, f. 136.

62 ASV. Segret. di Stato. Spagna 53, f. 156 y ss. 
de la que se enseña por arte y medianamente la castellana, y uno dellos medianamente la latina, como no son Theólogos ni saben los términos de esta facultad, no se an hecho con la verdad y seguridad devida. Y lo que es más de notar, que del que a leydo la Cátreda en Alcalá desta lengua ${ }^{63}$ dixo el Sr. Arçobispo que no avía sabido leer la letra de los libros, y de otro de los de Granada tenía Su S. ${ }^{a}$ poca sa-

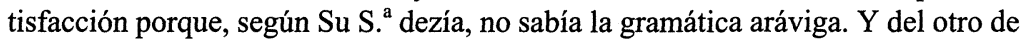
la mesma ciudad certificava Su S. ${ }^{a}$ que es tan ynepto que le harán dezir y desdeçir como quisieran y que a solas no es para ynterpretar cosa ninguna, y así se decía deste que aunque es el que sabe más de la lengua aráviga y el que sabe la latina ${ }^{64}$, le hacían desmenuçar tanto las partes de la sentencia que en presencia del Sr. Arçobispo y otros yva interpretando que aunque el diziese algún error o eregía que contenía la sentencia, le hacían con el menudear que la hiciesse correspondiese a católica.

Frente a ello, destaca su positiva actuación, hablando en tercera persona:

Un padre de la Compañía, que sabe algo de la lengua arábiga, con ocasión que tuvo de ir a aquella ciudad a pedimiento del Arzobispo vio, copió y interpretó algunos de los dichos libros ayudándose de otras lenguas que sabe y de las letras sagradas, y así dice que está satisfecho en si que interpretó y copió la verdad, y que todo es ansí como él lo entendió, y tiene por muy cierto que si discrepan los intérpretes en lo que toca a las sentencias y verdad de lo que él a dicho, no lo miraron bien.

Las críticas a Luna y Castillo, sin citarlos por sus nombres, se repiten en las cartas al Nuncio. En 1603 se defiende de la acusación del Arzobispo de no haberlo entendido bien y dice no fiarse de los dos intérpretes granadinos, en los que confía Castro, y cuyas traducciones no le parecen seguras. Reclama que se lleven a Roma y se traduzcan allí, donde hay quien podrá hacerlo con facilidad. Piensa en particular en los maronitas del Monte Líbano y otros cristianos orientales fieles a Roma. Él podrá darles la clave para interpretar los caracteres, si hiciera falta ${ }^{65}$.

Es significativo que la crítica de Las Casas coincide, desde ópticas radicalmente distintas, con la de Ahmad al-Haŷarī Bejarano, tal como nos la transmite Luis F. Bernabé Pons, quien en una interesante refle-

${ }^{63}$ Se trata del "arabista Diego de Urrea, profesor durante algún tiempo en Alcalá y autor de un breve catálogo de los manuscritos árabes existentes en la Biblioteca de El Escorial", Cabanelas, D., El morisco granadino, 213.

${ }^{64}$ Debe de referirse, sin duda, a Alonso del Castillo, y el "otro de los de Granada" debe de ser Miguel de Luna.

65 Las Casas al nuncio Ginnasio, Valencia, 27 de junio de 1603. ASV, Segr. di Stato. Spagna, 58, ff. 209-212. 
xión, señala cómo los múltiples sentidos que los textos podían recibir facilitaban multitud de lecturas que podían acomodarse a los destinatarios. En el caso del Arzobispo, éstas podían "edulcorar un mensaje demasiado islámico". El único riesgo que los traductores corrían era "ser acusados de desconocimiento del árabe o de no peritos en su traducción" "66. Es lo que hará Las Casas, que cree, en definitiva, que las traducciones son insuficientes - de lo que no parece salvarse la suya propia, que además no abarcó todos los libros-y que la solución está en formar como traductores de árabe a jovenes formados en Teología:

\footnotetext{
De estas dos cosas se concluie claro lo último que dixe, que no están bien hechas ni seguras las interpretaciones en cosa tan grave o importante de la Iglesia, y que es forzoso tomar el medio que allí apunté y es que theólogos mozos así de varias Religiones como otros deprendan en tres o quatro años la lengua arábiga y con esto se entenderá la verdad y servirán a la Iglesia y a estos Reynos no sólo en esto sino aun en lo que tengo apuntado en un tratado particular de ello ${ }^{67}$.
}

La poca consideración que le merece la capacidad intelectual de los intérpretes oficiales, Luna y Castillo, junto con su positiva valoración del contenido doctrinal de algunos de los libros plúmbeos, influirá decisivamente en su consideración de quiénes pueden ser, y sobre todo, no ser, los presuntos autores de los plomos.

Según Zótico Royo, ferviente defensor de las reliquias que utiliza la documentación del Sacromonte, Las Casas intentó llevarse parte de las copias y traducciones que había realizado, pero el Arzobispo logró, por intervención del Provincial, recuperarlas ${ }^{68}$. Es importante el dato, porque explica el que Las Casas en sus análisis de los plomos trabajase de memoria, como en ocasiones señala: "Tiene otras dificultades [...] que ay que notar en ellas como noté quando tenía el original y aora, por hablar sólo de memoria, no pue-

${ }^{66}$ Bernabé Pons, L. F., "Estudio preliminar" a la Historia verdadera del rey don Rodrigo, de Miguel de Luna, Granada, Universidad de Granada, 2001, XVI-XXII.

67 BL, Add. 57490, f. 136v. Debe de referirse al escrito: "Razones por las que se puede entender la importancia que ay en este tiempo que muchos teólogos, y en particular jesuitas, aprendan la lengua árabe", dirigido al P. Provincial Christóbal de los Cobos (Ávila, 23 de enero de 1607). BL, Add, 10238, ff. 195-237.

68 Royo, Z., Reliquias martiriales, 107. 
do" ${ }^{69}$. Sus materiales deben de conservarse, por tanto, en el Archivo de la Cartuja del Sacromonte. No obstante, la elaboración de los memoriales de denuncia le permitiría plasmar de inmediato sus recuerdos por escrito y completarlos con los abundantes tratados que circularon sobre los hallazgos del Sacromonte. En efecto, después de abandonar Granada, Ignacio de Las Casas va a desarrollar una campaña para tratar de evitar que se dé el visto bueno a las reliquias y a su soporte lógico, que son las láminas. Escribió primero, pidiéndoselo, al arzobispo de Granada "por una larga carta que le embié desde Valladolid" 70 . Pedro de Castro, en su respuesta, le amenazó con el desprestigio que caería sobre la Compañía de Jesús si seguía por ese camino. No le quedó, pues, más remedio que comunicar sus escrúpulos al Santo Oficio:

\footnotetext{
$\mathrm{Y}$ viendo por su respuesta que proseguía en su intento, ora fuese por pensar que no entendía yo los libros tan exactamente y que otros interpretavan o interpretarían de otra suerte $o$, lo que es más probable, por que tenía puesto todo lo hallado en aquella ciudad en los ojos del Rey, Prelados y Grandes de España en tan sumo grado que era difícil el desacerlo y particulamente haviendo gastado tantos millares de ducados, así en acomodar las cuevas como en autorizarlo todo, fui forzado de mi conciencia y por consejo de muchos doctos y cuerdos dar aviso al tribunal supremo de la Sta. Inquisición ${ }^{71}$.
}

En 1598 informó al Consejo de Inquisición y fue llamado a la Corte a declarar. Por estar el Inquisidor General, Portocarrero, indispuesto, trató con el inquisidor Zamora y pidió que no se calificasen las reliquias por el arzobispo Pedro de Castro hasta que la Iglesia no determinase la ortodoxia de la doctrina de los libros "por estar tan travados los libros con los huesos y cenizas y con lo hallado en la torre [Turpiana]" 72. Las Casas, en su escrito al papa Paulo V no se recata en criticar la falta de lógica del Inquisidor General, ganado a la causa de las reliquias:

\footnotetext{
Y siendo examinado por particular interrogatorio, respondí a las dificultades que se me opusieron y añadí al fin de lo procesado que suplicava a aquel Santo Tribunal que adbirtiese y considerase que no tenía la Iglesia de Dios necesidad en este tiempo de nuebas reliquias, aunque fuesen de los Apóstoles, y le estava

69 BL, Add. 57490, f. 106v.

70 Véase Alonso, C., Los apócrifos, 149-151.

71 BL, Add. 57490, f. 130

72 BL, Add. 10238, f. 178.
} 
mui bien que no se renovasen heregías antiguas, o se inventasen otras. Y aunque gratificó el Consejo mi ida y trabajo, cosa no usada en él, colegí de las palabras que últimamente a mi despedida me dijo el Inquisidor General Portocarrero que estava persuadido de el Arzobispo a apartar los libros y láminas de los huesos y cenizas, y de la Torre, porque me dijo que podía ser que las reliquias fuesen de santos y que hereges, sabiendo que lo eran, hubiesen puesto allí aquellos libros para autorizar su Doctrina. Y esto se ve quán imposible sea moralmente hablando y quán dañoso y peligroso, porque (como dixe al Inquisidor) cómo se puede decir que en la una parte que toca a las reliquias dice la lámina la verdad en decir que son de tal o tal santo, y mienta en decir que esos santos escribieron tal y tal libro ${ }^{73}$.

Es decir, le resultaba evidente que la separación artificial de la confirmación de la veracidad de las reliquias, que caía bajo la jurisdicción del Arzobispo, de la de los libros plúmbeos, que correspondía a Roma, atacaba la más elemental lógica, ya que eran éstos los que daban cuenta del origen de los huesos y cenizas. Pero dado que la calificación de las reliquias correspondía legalmente al Arzobispo y escapaba a la jurisdicción del Santo Ofício, se consideró obligado, nos dice, a avisar al Papa. No tuvo éxito ya que mientras tanto el arzobispo de Granada certificó la validez del hallazgo en abril de $1600{ }^{74}$.

En junio de ese mismo año, Las Casas se entrevista en Ávila con el Nuncio Ginnasio, a quien informa oralmente y por escrito de todo ${ }^{75}$, y quien le ordena que comunique a Roma cualquier nueva que tuviere "por ser causa, como su S. ${ }^{a}$ Ill. ma dixo, gravísima de la Iglesia". En 1604, estando ya destinado en Valencia, vio cartas del arzobispo de Granada al Rey en que manifestaba su deseo de que se autorizase la doctrina de los libros. No le quedó más remedio que hacer un memorial para Felipe III. Se enteró entonces de que el Papa había ordenado el traslado a Roma de los plomos, y añadió a su memorial un apéndice recalcando la necesidad de obedecer el mandato papal "en causa que era totalmente suya y tan justa", y sobre cuyas dificultades el Arzobispo no había informado. Como la muerte del Clemente VIII y la marcha del nuncio Ginnasio a Roma había paralizado el cumplimiento de la orden de traslado mientras "los daños que dello saldrán sin duda van echando más hondas rayzes", y siendo él "solo el que

${ }^{73}$ BL, Add. 57490, ff. 130v-131.

74 Sobre los avatares de la calificación y sobre los detalles de la actuación de Las Casas, la obra más completa es la ya citada de Carlos Alonso, adonde remito.

${ }^{75} \mathrm{Un}$ amplio informe de Las Casas fue enviado por el Nuncio a Roma el $1 .^{\circ}$ de julio de 1600. ASV, Segret. di Stato. Spagna, 53, ff. 157-165. 
penetró estos males", tuvo que volver a presionar al Santo Oficio. Es lo que hace desde Ávila, adonde había sido destinado, con el memorial de $1605^{76}$. Dos años más tarde, 1607, por mediación del nuncio Decio Carafa, escribía a Roma. La misiva principal iba dirigida al cardenal Belarmino, a quien había conocido durante su estancia romana. Le explicaba su actuación en el asunto de los libros plúmbeos y le enviaba un memorial para que informase al nuevo Papa, Paulo V. Otra más breve era para el cardenal Baronio, remitiéndole a la carta y memorial que habría recibido Belarmino.

Este memorial al Papa se articula, después de una introducción sobre los antecedentes, en tres tratados. En el primero da "Relación de todo lo sucedido en Granada y cerca de ella"; en el segundo, "Dícense en él las contradiciones que se han puesto en contra de todo lo hallado". El último y fundamental trata "De la doctrina de los libros". En su exposición separa la descripción de los hechos o del contenido de los escritos (pergamino, láminas, libros), de la crítica de los mismos, en que utiliza, y normalmente distingue, tanto argumentos ajenos como propios. Pero es consciente de que su originalidad radica en que conoce el contenido de algunos libros frente a los demás críticos que sólo conocían el pergamino y las láminas. Lo expresa al comenzar el último y más extenso tratado; refiriéndose a los dos anteriores dice: "Puesto he, Beatísimo Padre, la narración simple y llana de todo lo hallado que es lo material de esta información". Y, adelantando el contenido de la tercera parte, continúa: "Lo esencial de ella es la doctrina de los libros, en decir la qual me habré de detener algo más por lo que importa a la Iglesia" ${ }^{77}$. A partir de aquí repasa sucesivamente los libros sobre los que había trabajado de forma directa: Fundamentum Ecclesiae, Del anillo o sello de Salomón, la Historia de la verdad del Evangelio Glorioso, el libro del Ensalzamiento y el Ilegible. Y finalmente, antes de pasar a sacar las conclusiones generales y presentar un programa de acción, hace una breve observación sobre la Oración de Santiago. Por mi parte, voy a desviarme de su método y a exponer de forma condensada los principales aspectos de su crítica a la doctrina de los libros.

76 BL, Add. 10238, f. 179.

77 BL, Add. 57490, f. 105. 
Lo que más destaca Las Casas es el antitrinitarismo que de ellos se desprende. Ya lo observa en el pasaje del Fundamentum Ecclesiae relativo a la procesión de las personas divinas, donde dice: "Que el $\mathrm{Pa}-$ dre por el Espíritu Santo o con el Espíritu Santo engendra al Hijo". Y aunque, según reconoce, no haya encontrado la cita textual, ve en la afirmación resabios de las diversas y contrarias manifestaciones del antitrinitarismo antiguo que tanto influjo tuvo en España ${ }^{78}$ :

Véase claro que [el error] es el Noelo Savelico o Prisciliano o de los que decían que las Divinas Personas no son iguales como Arrio o de los Mataginmonitas, que significa los que ponen un vaso dentro de otro, a la qual parece que corresponde la de este libro, y es mucho de temer que sea así pues duró este error en España traido de los Godos que la ocuparon y poseyeron más de trescientos años, y Prisciliano, enseñado de sirios y caldeos en la Astrología Judiciaria y en los errores de Arrio, hizo gran daño en estos Reynos ${ }^{79}$.

Incluso las referencias a la inmaculada concepción de María, que tanta fuerza daban a los libros plúmbeos en la España de comienzos del siglo XVII, son interpretados por Las Casas como muestras de nestorianismo:

En éste - se refiere al Fundamentum Ecclesiae- está lo que dicen que ay en estos libros aprovando la puríssima concepción de Nra. Sra. porque (si bien me acuerdo) pone estas palabras: "Adán fue sin padre ni madre; Eva de padre sin madre; Jesús de madre sin padre, y en esta generación no alcanzó a María el pecado primero" 80 .

Pues bien, a pesar de manifestarse firme partidario, no se deja llevar por el entusiasmo inmaculadista y cree descubrir en el pasaje rememorado del libro plúmbeo la negación de la divinidad de Jesús, que habría sido introducido en el texto - que a él le cuesta asumir como totalmente falso- por influjo herético de los nestorianos. La

78 Como expone Manuel Sotomayor ("La Iglesia en la España romana", Historia de la Iglesia en España, García Villoslada, R. (dir.), Madrid, BAC, 1979, I. La Iglesia en la España romana y visigoda, 196-197) se trata de dos posiciones enfrentadas: "El sabelianismo afirmaba que Padre e Hijo eran solamente nombres diferentes, dos modos de existir del mismo y único Dios, dos aspectos de una única naturaleza o substancia divina, que se manifesta unas veces como Padre, otras como Hijo y otras como Espíritu Santo". Para distinguirse del sabelianismo Arrio afirmaba que el Hijo "1) Ha sido creado de la nada. 2) Hubo un tiempo en el que no existía . 3) Es mutable". Sobre el complejo problema del priscilianismo, véase id., cap. VII, 233-272.

79 BL, Add. 57490 , f. $106 \mathrm{v}-107$.

${ }^{80}$ Id., f. 106. 
exclusión del pecado original no habría afectado a la concepción de María por parte de Santa Ana, como defenderá el dogma de la Inmaculada, sino a la de Jesús:

\footnotetext{
En lo que dice de la Puríssima Concepción de la Nra. Sra., aunque el lugar es bueno para lo que deseamos ver de Fee, se puede explicar que quando María concibió al Hijo de Dios no alcanzó a la Sacratísima Humanidad el pecado original, y si el libro fue corrompido por hereges, y más Nestorianos, más parece que tira a esto negarle la Divinidad que es lo que pretenden estos libros secretamente y dándole lo que nosotros damos a su sacratíssima madre ${ }^{81}$.
}

Pero el núcleo básico de la controversia es la frase incorporada al sello de Salomón y reiteradamente repetida en los libros: "No hay Dios sino Dios, Jesús Espíritu de Dios". La frase había sido objeto de un análisis filológico muy preciso por parte de Benito Arias Montano; un análisis demoledor para las intenciones del arzobispo Castro que le había mandado una copia de lo escrito en "caracteres salomónicos" junto con la lectura que habían hecho los intérpretes, a los que el humanista no puede dejar de calificar de adivinos ${ }^{82}$. "La fórmula: LA ALAH ILA ALAHV es communíssima entre los árabes y moros". En cuanto al término "RVHHV que V. S. a me manda interpretar digo que es vocablo arábigo [... que] simplemente y en rigor [...] significa spiritu". Rechaza en consecuencia que pueda interpretarse como 'sustancia', 'naturaleza', 'alma'... y mucho menos 'hijo'. La lectura de Ignacio de Las Casas concuerda plenamente con la de Arias Montano - "En ninguna parte de ningún libro llama a Jesús Hijo de Dios sino Espíritu de Dios"-, cuyos escritos conoce:

Aviendo entendido esto por cartas, la buena memoria de Benito Arias Montano, que le escribió el Arzobispo, le respondió que temía y aun tenía por probable que los libros hallados eran cosas de hereges pues usavan este término y frasi en todos ellos. Y aunque se le hicieron argumentos de que la Sagrada Escritura llama al Hijo de Dios Espíritu de Dios, y ello es así, jamás le pudieran sacar de su parecer por no decir (siquiera alguna vez) - hijo- . Y así nunca le pudo inducir el Arzobispo a querer corresponder con lo que tan aincadamente le suplicaba de venir a Granada, por no parecer que autorizaba aquello con su presencia. Vi yo cartas suias sobre esto y en todas decía llanamente que temía que eran engaños de

81 Id., f. 109.

82 "Y entiendo que quien las leyó y saco de ellas equivalencia de vocablos bien scrittos fue buen adivino o, a lo menos, las descifró con asaz trabajo y espacio" (Morocho, G., Estudio introductorio, 388-389). 
hereges, y si esto decía con sola una bislumbre sin saber lo particular de la doctrina de los libros, qué dixera si la supiera ${ }^{83}$.

Pero frente a la visión de Benito Arias, que señala directamente el influjo islámico, Las Casas, una vez más, apunta a un origen herético de raíz cristiana ${ }^{84}$ :

Es el símbolo que tuvieron los Nestorianos y Arrianos para negar la Divinidad de Jesú Christo y de los demás hereges antecesores lo tomaron los sequaces de Mahoma y lo han usado siempre y usan oy de ella en esta forma: "No hay otro Dios sino Dios y Mahoma su enviado" con la qual profesan su falsa secta. Quando hablan de Jesús la entienden así: "¡No hay otro Dios sino Dios no dividido en personas y Jesús es hombre puro participante de su espíritu”, entendiendo aquella palabra Espíritu de Dios instrumentalmente ${ }^{85}$.

Y poco después concluye insistiendo en la misma idea: al incluir el sello de Salomón, con la leyenda mencionada, en los libros plúmbeos, se quería legitimar la doctrina "de los Nestorianos de los quales ay muchos hasta oy en Oriente" por medio de la intervención de la Virgen que era quien había relatado la historia del sello y mandado que se escribiese. Frente a la exclusividad islámica que señalan otros autores, entre ellos Arias Montano, como fuente de inspiración de la frase "No hay Dios sino Dios, Jesús Espíritu de Dios", el P. Las Casas defiende las raíces antitrinitarias preislámicas de la doctrina de los libros, que perviven en algunas comunidades orientales.

El sello de Salomón introduce, además, otro de los puntos básicos de la crítica del jesuita contra los libros plúmbeos y el pergamino de la torre que los antecedió. Ataca duramente Las Casas el universo profético y mágico que envuelve y penetra todos los hallazgos granadinos. Y del ataque no se salva el propio Salomón y los que defienden que tuvo poderes para exorcizar demonios. El problema es que en la historia del sello "la Virgen contó a los Apóstoles que Salomón tubo un sello o anillo en el qual tubo encerrado todo su saber y sciencia y

${ }^{83}$ BL, Add. 57490, f. 111.

84 Ibid., f. 110.

85 Hace referencia a "un libro que precian los Mahometanos cuyo título es Alvum Dafi Xarchi al burda [sigue el título en una imitación de caracteres árabes], que es la profundidad en la exposición de la Borda. Es esta Borda una canción o elegía que trata de Mahoma exponiéndola un antiguo tenido por gran Doctor entre los Áraves". En él se "trata largamente lo que de Nro Redemptor dicen el Alcorán y sus expositores, quitándole la divinidad y diciendo que lo que se dice que es Espíritu de Dios, Alma o Palabra es instrumentalmente". 
con él sujetaba los espíritus y los hombres, las bestias, el mar y los vientos" ${ }^{86}$. La historia encaja bien en la tradición cristiana, aceptada incluso por el propio cardenal Baronio, que atribuía a Salomón el poder de conjurar espíritus, ciencia en la que se habrían instruido los judíos hasta la venida de Cristo:

Todo lo dicho parece prueba que Salomón no sólo tuvo sciencia contra los Demonios sino que la dejó enseñada y que se usó hasta Nuestro Redemptor y que según esto será verosimil esta historia del sello o absolutamente verdadera y más siendo referida por la Virgen como en ella se dice.

La postura de Ignacio de Las Casas se enfrenta a la aprobación tácita por la tradición eclesiástica - incluyendo a César Baronio- del comportamiento de Salomón. Para el jesuita la adivinación no la inspira Dios; en todo caso se efectuará por conocimientos naturales ${ }^{87}$. En cuanto al dominio sobre los espíritus, dado que la naturaleza humana es inferior a la de los espíritus, los exorcismos exigen un poder sobrenatural. Este poder será santo o diabólico, inspirado por Dios o logrado por pacto diabólico, pero no es un arte natural que pueda enseñarse. En el fondo su opinión del sabio Salomón es bastante negativa:

Cometió el maior pecado de todos que es Idolatría y culto a los Demonios, engañado de ellos, y por esto por ventura permitió Dios que se quemasen obras suias como no solamente inútiles a la república sino aun perniciosas y dañosas. Y por ser tal la que llaman Clavicula Salomonis o Fabula Salomonis está prohivida por la Sta. Iglesia Romana.

Y si alguien insistiese en que Salomón enseñó el arte de conjurar espíritus, le replicaría que "contenía pacto tácito o expreso con los Demonios y para engañar ellos con esto a los hombres, como hazen hasta oy, se muestran ser constreñidos y salir y no bolber" 88 . Sin duda su trabajo como intérprete de la Inquisición valenciana le ha familiarizado con la postura del Santo Oficio. En el fondo se resiste a creer

${ }^{86}$ Gaspar Morocho (Estudio introductorio, 285-286) recoge una larga cita de este pasaje de Las Casas en que relata la historia del sello.

87 "Tengo para mí que el sapientíssimo Salomón no ensenó cosa que no fuese natural y particular estudio suio para llegar a saver quanto sabían los hechizeros y encantadores de su tiempo como los de Pharaón en el de Moysés [Al margen: Deutron. 18; $1 .^{\circ}$ Reg. 28; 4. ${ }^{\circ}$ Reg. $23 ; 1 .^{\circ}$ Paralip. 10], porque no me cuadra decir que aquel Señor que prohibió con pena de muerte a los Israelitas los Pythones y Pithonisas le diese a Salomón tal arte"; BL, Add. 57490 , ff. $114 \mathrm{v}-115$.

${ }^{88} I d$., f. $115 \mathrm{v}$. 
que el sello de Salomón tenga poderes sobrenaturales. De ahí su rechazo a la doctrina de un libro en el que la Virgen aparece como garante de tal historia. Y concluye sobre las particulares virtudes del sello:

¿Quién no ve que aunque son galanos discursos, no son fundados ni tienen autoridad aunque se añada que en ellos se incluya y encierre el santo nombre de Dios y en quanto encierra sciencia cabalística? Usan oy de este sello, en la misma forma y con el mismo nombre, los mahometanos en sus conjuros, y casi no ay libro de agüeros y hechicerías donde no le pongan ${ }^{89}$.

Pero, además del asunto del anillo de Salomón, su crítica se dirige contra todo el fondo profético que inspira el conjunto de los hallazgos desde el pergamino de la torre Turpiana. La validez profética de las referencias a Mahoma y Lutero, que en él se hacían, había sido desmontada por los críticos de la antigüedad material del pergamino, como Arias Montano o González de Valcárcel, cuyos escritos conoce y utiliza Las Casas. Se detiene especialmente en el pasaje del Fundamentum Ecclesiae en que se anuncia que se descubrirá el libro cuando se entierren en los templos los malos con los santos. "Ya se ve - escribe Las Casas - que es señal sin fundamento, pues desde que ay templos se comenzaron a enterrar los fieles [...] con los malos". En definitiva, su argumento es que si la profecía hubiera sido cierta debían haberse encontrado hace muchos años. Y si se quiere interpretar en el sentido de que cuando habla de infieles se refiere a los moriscos o a los judeoconversos, rechaza que pueda admitirse el argumento, ya que para la Iglesia los bautizados son hijos suyos y, salvo los condenados por herejes, acepta enterrar a todos:

Y si se dixese que habla del enterrarse los infieles en los lugares sagrados juntamente con los fieles, tomando a los infieles por los descendientes de Mahoma, o de otros no bien combertidos, o que no creen como deven, aun hallaremos que así no lleva fundamento poner tal señal, pues la Iglesia, que no juzga lo oculto de los corazones, los recive como hijos ${ }^{90}$.

En consecuencia, tampoco ésta puede considerarse como una verdadera profecía. El mayor peligro por el contenido profético lo tiene, en su opinión, el conjunto de hallazgos del 31 de diciembre de 1597,

89 Id., f. 116.

$90 I d$., f. $107-108$. 
que incluye el libro Ilegible, la Historia de la verdad del Evangelio Glorioso y el libro del Ensalzamiento. No porque se hubieran producido los milagros anunciados en la Historia de la verdad del Evangelio - lo que aprovecha para criticar al arzobispo Castro ${ }^{91}$ - , sino por el planteamiento global, por el juego entre el Ilegible y la Historia, complementado por alusiones en el Ensalzamiento. El primero, como indica el nombre que Las Casas le da, no se pudo interpretar salvo "su título, que es Haquiqat Al ingili, que es Verdad del Evangelio" y "ocho elegantes versos en arábigo - contenidos en la primera hojaque declaran su excelencia en esta forma: «Certidumbre de el Evangelio que derribará todos los estandartes. Dichoso el que lo recibiere con el espíritu y corazón, y desdichado del que no lo creyere»" "92. El mensaje fundamental estaba contenido en el libro que refería la historia del Ilegible y que fue dictado por Santiago a su discípulo S. Tesifón en las mismas cuevas en las que se encontró. Relata que después de la Ascensión juntó la Virgen a los Apóstoles y les mostró dos libros, uno, original, le había traído del cielo el ángel Gabriel, "el qual tenía notables resplandores celestiales y maravillosa lindeza y hermosura que lengua no la sabría decir, y el otro era de plomo transladado de este celestial, sellado por mano de la Virgen con el sello de Salomón, de quien ella descendía" ${ }^{33}$. Después "salió la Virgen con los Apóstoles al monte Olivete y orando allí vino una luz y tomó el libro original y desapareció. Tornada la Virgen a su estancia mandó a Santiago que juntase a sus Discípulos y juntos les dio dos libros - el Ilgegible y el del Ensalzamiento - y mandó se fuesen a embarcar para España". Debían embarcarse en una nave cuyo piloto sería el ángel Gabriel, entrar en España por la parte oriental y guardar el libro donde resucitase un muerto. Les mandaba "que honrasen y venerasen en

\footnotetext{
91 "Una cosa es claramente falsa en el 5..$^{\circ}$ punto que descubiertos los libros obraría Dios tantos y tales milagros del Cielo y de la Tierra en aquel lugar que combencerían aun a los mui incrédulos. Porque hasta oy no ha avido ninguno tal, $\mathrm{y}$ han pasado muchos años y ay muchos tanto dentro de aquella ciudad de Granada como fuera que jamás han dado fee a nada de lo hallado y son sin número los que no creen nada de ello en comparación de los que lo creen. Y aun el Arzobispo esperaba ver exquisitos milagros en esto, como luces o música del cielo, o descender ángeles visiblemente, como lo trató conmigo algunas vezes"; B1, Add. 57490, ff. 121v-122.

${ }^{92}$ Ibid., ff. 127v-128. Las Casas sólo traduce una parte y añade: "Pone otros encarecimientos en estos versos". La traducción del marqués de Estepa puede verse en Hagerty, M. J., Los libros plúmbeos, apéndice IV.

93 BL, Add. 57490, f. 118.
} 
aquel monte porque después de los de Jerusalem era el maior y más sagrado", donde muchos de ellos morirían mártires y donde guardarían sus libros "para direción y guía en el fin del Mundo". En el libro "dice Santiago que cumplió quanto le dijo la Virgen y halló la nave y piloto \&". En definitiva confirma la venida a España de Santiago con la particularidad de que el lugar santo principal son "las cuevas dichas sobre el Río Darro, que así le llama aunque con término arábigo", apostilla Las Casas.

Si estas noticias, puestas en boca de María, eran sumamente atractivas para los defensores del mito Jacobeo, lo que iba a suceder a partir del descubrimiento de los libros lo era para los moriscos:

4 Llegado el tiempo que se descubriese clamarían a Dios los Ángeles y Patriarcas y Dios los oiría y San Gabriel daría un grito y así se abriría el lugar do estarían escondidos estos libros.

5 Descubiertos, obraría Dios tantos y tales milagros del Cielo y de la Tierra que combencerían a los mismos incrédulos.

6 Quando se descubriesen los libros codiciarían los habitadores de aquella tierra saver lo que contenían.

7 Que se juntarían intérpretes para interpretar lo que estaría en arábigo.

8 Que en aquel tiempo la lengua arábiga sería la común y usada en aquellas tierras.

9 Que quando se descubriessen estos libros movería Dios en Oriente el ánimo de un Rey árabe el qual con sus exércitos de árabes viniese a defender y amparar la verdad del Evangelio glorioso.

10 Este Rey árabe con su exército de árabes vendría sujetando lo más de esta tierra hasta estos Reynos.

11 Que los árabes son de las mejores naciones del mundo y su lengua de las mejores.

12 Que los judíos que crucificaron a Jesús, ellos y sus descendientes hasta el juicio no se salvarían.

13 Que Dios ha escogido a los áraves y a este Rey árave para amparar la verdad del Evangelio y para esto les dará saver y potencia.

14 Que este rey árave haviendo sugetado la tierra juntaría la voluntad de los Reyes para que juntasen un concilio universal en una isla y en una ciudad de ella.

15 Que este concilio será para tratar de la verdad de la doctrina del libro ensalzamiento \& que está con el ilegible.

16 Sobre esta doctrina avrá grandes disputas entre los doctos de la sciencia única.

17 Que se fatigarían con penitencias y humillaciones para entender el ilegible y no podrán.

18 Embiará Dios un hombre humilde y bajo que con la luz del Espíritu Santo lo leerá y interpretará y le creeran todos.

19 Interpretando verán todos claro que han seguido mal el Evangelio y su interpretación y la del testamento viejo. 
20 Creerán a la Doctrina del que está con él que es el del Ensalzamiento.

21 Serán dichosos y venditos los que se hallaren en este concilio y obedecieren y malditos y desdichados los que no quisieren ir a él ni creerle.

22 Declarado el ilegible y admitida la doctrina del otro que está con él, por éste se convertirán muchos a la verdad.

23 Seguirán todos estas verdades y cesarán las heregías y será la ley una por un poco de tiempo y después tornarán a pervertirse.

24 Tras esto vendrá el Antichristo con mayores milagros que los dichos ${ }^{94}$.

Es decir, presentaba un programa milenarista donde los árabes, triunfadores políticos y culturales, serían los encargados de ofrecer una interpretación correcta del libro revelado y lograr el triunfo de la única fe, antes de la venida del Anticristo. No se le escaparon a Ignacio de Las Casas las amenazas que este programa implicaba, no tanto por lo que dice de "la lengua y Nación Árave queriéndola engrandecer y apoyar sin fundamento, no porque la Nación Árave no sea apta a qualquier bien si se rindiese al yugo del Evangelio, y la lengua es galana, copiosa y afectuosa, pero, como oy está, casi toda ella es enemiga del Evangelio y tan contraria como se ve" ${ }^{95}$. El problema se derivaba de que la exaltación mesiánica de la Historia de la verdad del Evangelio glorioso concordaba plenamente con las expectativas que mantenían entre los moriscos todo un conjunto de profecías:

Andan en España, entre los no bien conbertidos, librillos de profecías de su Engañador y de otros que ellos tienen por Profetas que dicen que jamás hasta la fin del mundo dejará de haver en España verdaderos seguidores de Mahoma, hermitas y oratorios suios, y esto aunque más los atormenten y maten, y que han de levantar caveza y sugetar otra vez estos Reynos destruiendo la Ley Evangélica, y a esto parece que tiran todos los puntos dichos ${ }^{96}$.

Y era especialmente peligroso el anuncio del rey árabe no sólo para la Monarquía Católica, ya que podía animar las rebeliones moriscas, sino para la propia Iglesia Romana por el aprovechamiento que de los textos podían hacer sus múltiples enemigos.

El decir que ha de venir un Rey Oriental Árave con su exercito de áraves sujetando el orbe así como es perniciosíssimo para estos Reynos por haver tantos millares de esta nación en ellos que no se han rendido al Evangelio como se desea, así también lo es para esa Silla Apostólica por tener solevantados contra la Iglesia

94 Id., ff. $117 \mathrm{v}-119 \mathrm{v}$.

95 Id., f. 122.

96 Id., ff. $122 \mathrm{v}-123$. 
no sólo los Áraves Orientales sino tantos Judíos, cismáticos y hereges dudando si está establecida sobre firme piedra, pues dice esto de ella Nra. Sra. y atreviéndose a acometerla y turbarla por varias vías.

No se le ocultaba tampoco al P. Las Casas los peligros contenidos en el programa centrado en el contenido del libro ilegible. Significaba que la Iglesia no había transmitido correctamente la revelación y que ésta estaba incompleta:

Primero, parece claro que el decir que lo contenido en aquel libro ilegible no era para los Apóstoles sino para la perfecta guarda del Evangelio en el fin del Mundo es decir que la ley Evangélica no está perfectamente promulgada por los Apóstoles por que no se dé tanta fee a la Iglesia esperando la promulgación perfecta ${ }^{97}$.

Es ésta una de las ideas que, como reconoce, más podía afectar a los moriscos - junto con la esperanza mesiánica-; existe el peligro de "que se persuadan, con maior pertinacia que hasta aquí, que la Ley Evangélica no es la que sigue la Iglesia" ${ }^{98}$. No capta en cambio, o al menos no lo manifiesta, que el libro ilegible se inserta en un diferente modelo de revelación ya que no se trata de una obra de autor humano inspirado por Dios, sino de un libro que proviene directamente de Dios ${ }^{99}$.

En definitiva, para Ignacio de Las Casas existe una relación estrecha entre los plomos y el problema morisco. Lo expone en reiteradas ocasiones, como por ejemplo en su memorial a la Suprema, en un párrafo que resume perfectamente el atractivo que la doctrina de los libros plúmbeos presenta para los moriscos 100 :

La travaçón que tiene todo esto de Granada con lo de los moriscos es claríssima porque como tengo ya dicho siendo estos libros en arábigo, que es la lengua en que ellos creen que está la verdad y certidumbre de la escripturas sagradas y en sola la qual habla Dios con veras lo que pertenece a la fe, tienen por muy cierto que estos libros son verdad y que diziendo en ellos la Virgen que a de venir un Rey Árabe y sugetar la tierra y que en la junta y Concilio que a de hazer juntar an de ver todos que no avemos seguido bien el Evangelio ni las scrituras, correspon-

97 Ibid., 120v.

98 Ibid., f. 135.

99 Véase a este respecto la importante tesis de Luis F. Bartolomé Pons sobre el evangelio apócrifo de San Bernabé (Bernabé Pons, L. F., El evangelio de San Bernabé. Un evangelio islámico español, Universidad de Alicante, 1995).

${ }^{100}$ BL, Add., 10238, f. 187. 
de con lo que ellos tienen por verdad de su Alcorán, que nuestro Evangelio está depravado y no es el que enseñó Jesu Christo, y tienen también por çierto que es verdad lo que tengo dicho que España a de ser otra vez suya y todos los della an de seguir la secta de su perverso Mahoma, y entendiendo como entienden que lo de los libros lo dixo la Virgen házese este error más pertinaz en sus entendimientos y más peligroso para estos Reynos como se a dicho. Y no se ve otro remedio que el darles a entender claramente ser todo esto invención de enemigos de Dios y de su Iglesia por la mejor vía que se hallare.

Ante este peligro debe evitarse la divulgación del contenido de los libros, aunque sea indirecta, a través de lo que refieren otros autores. El sentimiento mesiánico de los moriscos es tan fuerte, según exponía Las Casas al Santo Oficio, que leen con avidez

\begin{abstract}
libros de historias [en que] se tocan cosas de los moros como los que a sacado Miguel de Luna ${ }^{101}$ y en particular la segunda parte en la que autoriza demasiado las cosas de los moros, sus ingenios, govierno, obras y virtudes y las engrandece demasiado: escrive vidas de moros y hechos y dichos suyos que se pueden, para gente no asentada en la fe, comparar con nuestros sanctos que es para estos gravíssimo daño. Atribuye a los moros victorias con otros favores y misericordias como dones de Dios a amigos suyos. Véase con esta consideración toda la vida del Rey Jacob Almançor. Algo destos inconvenientes tiene el libro que sacó Luis del Mármol por los pronósticos que pone suyos porque los tienen por ciertos como diré. Compran ellos estos libros en saliendo y causándoles el resfriarse del todo en la fe, los encienden e inflaman en sus cosas ${ }^{102}$.
\end{abstract}

Sin embargo, no es de la opinión que "lo de Granada" sea obra de los moriscos, sino que sus autores deben ser "orientales" —en el sentido actual del "próximo oriente"- de lengua árabe, tanto cristianos heréticos y cismáticos como musulmanes. La razón principal que ale-

101 Se refiere a la Historia verdadera del rey don Rodrigo en la cual se trata la causa principal de la pérdida de España y la conquista que della hizo Miramamolín Almançor ... y vida del rey Iacobo Almançor, atribuida a Abulcácim Tárif Abentarique y de la que Miguel de Luna aparece como traductor de un manuscrito encontrado en la biblioteca de El Escorial. La primera parte se publicó en Granada en 1592 y la segunda, también en Granada, en 1600. Véase la interpretación de Francisco Márquez Villanueva, "La voluntad de leyenda de Miguel de Luna", El problema morisco (desde otras laderas), Madrid, 1991, 45-97. Véase la ya citada edición facsímil publicada por la Universidad de Granada con un estudio introductorio de Luis F. Bernabé Pons.

102 BL, Add., 10238, f. 170v. En el memorial al Papa cita además, entre otros, a Fernández de Velasco, J., Dos discursos en que se defiende la venida y predicacion del apostol Santiago en España / sacados de la libreria de Iuan de Velasco..., Amberes por Iuan Hetsroy, 1608; Pineda, J. de, S. J., Commentariorum in Iob, Sevilla, 1601; Ariz, L., O. S. B., Historia de las grandezas de la ciudad de Auila, Alcalá, 1607. 
ga es el conocimiento que muestran de aspectos del Cristianismo que superan los de los moriscos y enlazan con las herejías antiguas que perviven en Oriente. Algunas citas justificativas:

Eran los que escribieron estos libros elegantes Arábigos Orientales no mal pláticos de los lugares santos de Jerusalem, y que se esmeraron en el estilo aunque a cada paso ponen cosas no tan pertinentes y creíbles ${ }^{103}$.

En otro pasaje rechaza decididamente la intervención de los moriscos:

Decir que es inbención de Mahometanos o Moriscos de aquel Reyno [de Granada] tampoco me quadra. La razón es ver que los libros tienen cosas mui bien puestas de la Ley Evangélica y por términos que no los usan los Mahometanos y son propios de los christianos orientales, y los herrores son de los scismáticos de aquellas partes. Por lo qual se me haze probable que han sido varios los autores de todo esto, mezclados de scismáticos orientales, hereges y Mahometanos, de todos los quales suelen venir muchos en España y más en aquel Reyno de Granada. Persuádeme más a creer esto el haber yo topado en estos Reynos, y fuera de ellos, astutísima y atrevidísima gente de los dichos ${ }^{104}$.

En todo caso, la participación morisca sería secundaria; una de sus críticas a las reliquias - cuya autenticidad, por otra parte, ya había sido aceptada por la Iglesia granadina - se basa en recordar que se hallaron en el antiguo cementerio judío de Granada. Su malévola interpretación es que los huesos y cenizas serían restos de tal cementerio utilizado por los musulmanes como caleras y que, finalmente, habrían sido aprovechadas para colocar allí los plomos. Pero incluso en este supuesto, la intervención de los "naturales" sería de mera colaboración:

Saviendo los mahometanos que havía allí cuerpos de judíos [es posible que] huviesen, por el odio natural que les tienen y por desprecio y befa, hecho allí sus caleras y combertídolos (como dicen) en cal, dejando allí sepultada la parte inútil de ella, y allegando a saber algo de esto algunos de los descendientes de mahometanos juntos con hereges orientales de la lengua arábiga y septentrionales hubiesen querido, por sus intereses, burlarse de la Iglesia latina y turbarla con semejantes novedades ${ }^{105}$.

Reconozco la dificultad de asumir estas tesis, pero junto a ello el conocimiento que Ignacio Las Casas tenía de la realidad granadina.

103 BL, Add. 57490, f. $123 \mathrm{v}$.

104 Id., f. 137.

$105 I d$., f. $104 \mathrm{v}$. 
Es posible que su desprecio, ya señalado, por los intérpretes Alonso del Castillo y Miguel de Luna, junto con su valoración positiva de algunos de los libros por él traducidos, como el Fundamentum Ecclesiae, le hiciera rechazar la que luego se ha convertido en la explicación dominante al considerarlos insuficientemente preparados. Me planteo si tendría otras razones de tipo político, ya que en definitiva su intención última era influir en la toma de decisiones sobre los hallazgos. Una mera autoría morisca quitaba importancia al problema. Para conseguir interesar al Papa, como él intenta, la amenaza de la revitalización de antiguas herejías antitrinitarias parece un argumento de más peso que unos escritos mesiánicos y milenaristas elaborados por unos moriscos sin preparación teológica ${ }^{106}$. Pero entonces, ¿cómo explicar la abundancia de referencias islámicas que Las Casas denuncia en su memorial? En el complejo asunto de los libros plúmbeos, el deseo de separar las cosas inciertas de las ciertas, como quería Arias Montano, resulta una meta escurridiza. Sin embargo, la visión de un testigo de primera importancia, como lo es Ignacio de Las Casas, enriquece nuestro conocimiento sobre "los libros hallados en Valparaíso de Granada".

\section{RESUMEN}

El jesuita morisco P. Ignacio de las Casas colaboró en la traducción de algunos de los libros plúmbeos encontrados en Granada a fines del siglo XVI. Inicialmente se manifestó partidario de su autenticidad, pero pronto se convenció de que eran una falsificación. Desarrolló entonces una activa lucha para conseguir que la Iglesia evitara su divulgación. En el artículo se pasa revista a su intervención como traductor y a los argumentos que utilizó para criticar la doctrina de los libros plúmbeos. El P. Las Casas, además de señalar la presencia de elementos islámicos, ve en ellos claras muestras de antiguas herejías antitrinitarias. Aunque no los considera obra de moriscos, señala el atractivo que el mesianismo y milenarismo contenidos en la doctrina de los libros plúmbeos tenía para los moriscos.

106 En su carta de 1600 al nuncio Ginnasio dice: "No se dice esto por entender que sean los libros cosas de moros, que no lo son sino muy más antiguas del tiempo por ventura de los arrianos y de otros hereges tales que en España ha avido"; ASV, Segr. di Stato. Spagna, 53 , f. $163 \mathrm{v}$. 


\begin{abstract}
The Morisco Jesuit P. Ignacio de Las Casas collaborated in the translation of some of the lead books found in Granada at the end of the 16th century. At first he was a partisan of their authenticity, but he rapidly became convinced that they were false. There followed a fierce struggle to make the Church prevent their publication. In the article his activity as a translator of these texts is reviewed, together with the arguments, which he used in order to criticise the doctrine contained in the lead books. In addition to noting the presence of Islamic elements, de Las Casas saw in them clear signs of ancient anti-trinitarian heresies. Although he does not consider them the work of Moriscos, he notes the attraction which the messianism and millenarianism in the doctrine of the lead books had for the Moriscos.
\end{abstract}

